\title{
THE UNITED STATES
}
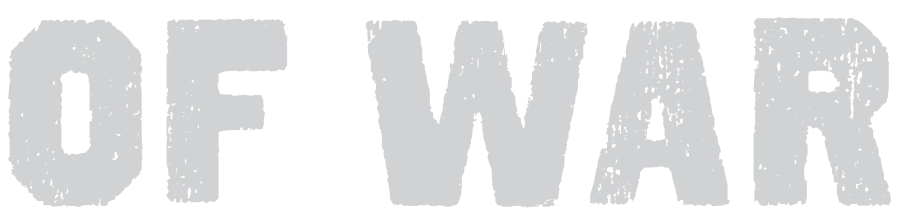


\section{CALIFORNIA SERIES IN PUBLIC ANTHROPOLOGY}

The California Series in Public Anthropology emphasizes the anthropologist's role as an engaged intellectual. It continues anthropology's commitment to being an ethnographic witness, to describing, in human terms, how life is lived beyond the borders of many readers' experiences. But it also adds a commitment, through ethnography, to reframing the terms of public debate-transforming received, accepted understandings of social issues with new insights, new framings.

Series Editor: Robert Borofsky (Hawai'i Pacific University)

Contributing Editors: Philippe Bourgois (UCLA), Paul Farmer (Partners in Health), Alex Hinton (Rutgers University), Carolyn Nordstrom (University of Notre Dame), and Nancy Scheper-Hughes (UC Berkeley)

University of California Press Editor: Naomi Schneider 


\section{THE UNITED STATES}
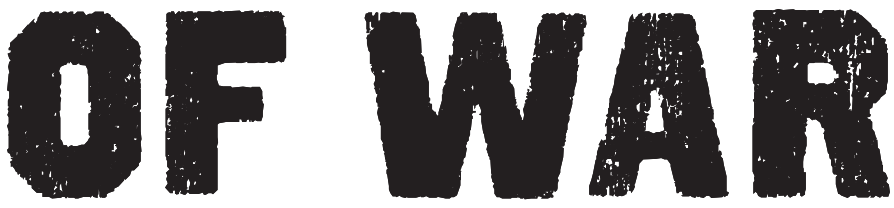

A GLOBAL HISTORY OF AMERICA'S

ENDLESS CONFLICTS, FROM

COLUMBUS TO THE ISLAMIC STATE

\section{DAVID VINE}

甲

UNIVERSITY OF CALIFORNIA PRESS 
The author will donate all proceeds from this book's royalties to nonprofit organizations serving victims of war and other forms of violence.

University of California Press

Oakland, California

(C) 2020 by David Vine

Maps, except where noted, are by Kelly Martin Design. Earlier versions of some maps first appeared in David Vine, Base Nation: How U.S. Military Bases Abroad Harm America and the World (New York: Metropolitan Books, 2015).

Library of Congress Cataloging-in-Publication Data

Names: Vine, David, 1974- author.

Title: The United States of war : a global history of America's endless conflicts, from Columbus to the Islamic State / David Vine.

Other titles: California series in public anthropology.

Description: Oakland, California : University of California Press, [2020] | Series: California series in public anthropology | Includes bibliographical references and index.

Identifiers: LCCN 2020006465 (print) | LCCN 2020006466 (ebook) | ISBN 9780520300873 (cloth) | ISBN 9780520972070 (ebook)

Subjects: LCSH: United States-History, Military. | United StatesHistory, Military-Social aspects. | United States-Military policyHistory. | United States-Foreign relations. | United States-History. Classification: LCC E181 .v65 2020 (print) | LCC E181 (ebook) | DDC $355.00973-\mathrm{dc} 23$

LC record available at https://lccn.loc.gov/2020006465

LC ebook record available at https://lecn.loc.gov/2020006466

Manufactured in the United States of America

$\begin{array}{lllllllll}28 & 27 & 26 & 25 & 24 & 23 & 22 & 21 & 20\end{array}$

$\begin{array}{llllllllll}10 & 9 & 8 & 7 & 6 & 5 & 4 & 3 & 2 & 1\end{array}$ 
To my parents and siblings. I love you dearly and forever. 
If we divide reality into two camps-the violent and the nonviolentand stand in one camp while attacking the other, the world will never have peace. We will always blame and condemn those we feel are responsible for wars and social injustice, without recognizing the degree of violence in ourselves. We must work on ourselves and also with those we condemn if we want to have a real impact.

Thich Nhat Hanh, Love in Action: Writings on Nonviolent Social Change 